\title{
Determination of the histological distribution of insulin like growth factor 1 receptors in the rat gut
}

\author{
J Ryan, D C Costigan
}

\begin{abstract}
The histological distribution of insulin like growth factor 1 (IGF 1) receptors in the rat gut was studied. Immunostaining of IGF 1 receptors identified localisation on the villus epithelium, in the crypts, and in Brunner's glands of the small intestine. These tissues represent areas of high cell growth/differentiation, division, and macromolecular synthesis respectively, which constitute biological activities long associated with IGF 1. Cellular localisation of IGF 1 receptors was seen in the lamina propria by IGF 1 receptor immunostaining and ligand binding of biotinylated IGF 1. IGF 1 receptor immunostaining in the spleen showed receptor localisation to the splenic pulp thus pointing to macrophages as the possible IGF 1 receptor positive cells in the lamina propria. The results further implicate IGF 1 as an important growth factor in gut maintenance.
\end{abstract}

(Gut 1993; 34: 1693-1697)

Insulin like growth factor 1 (IGF 1 ) is a low molecular mass peptide found in highest concentrations in serum. IGF 1 acts through signal transduction by a cytoplasmic tissue kinase function associated with the cell surface membrane receptor. ${ }^{1}$ Biological activities attributed to IGF 1 include stimulation of mitogenesis and macromolecular synthesis. ${ }^{23}$

The gastrointestinal tract is an organ of rapid growth, the rate of cell division and differentiation in the gastrointestinal mucosa being one of the most rapid proliferative rates in the body. ${ }^{4}$ The factors promoting the rapid rate of cell division and differentiation in intestinal mucosa are largely unknown. In recent years attention has been focused on a possible role for IGF 1 . IGF 1 activity is mediated through the IGF 1 receptor, and consequently IGF 1 receptor topology has been investigated. Laburthe et $a l^{, 5}$ showed appreciable concentrations of specific IGF 1 binding in rat gut, while Pillion et al, ${ }^{6}$ showed IGF 1 binding on proximal colon epithelial apical membranes. More recently type 1 IGF receptors were seen in porcine small intestine. These studies used radioactively labelled IGF 1 in competitive binding to tissue membranes prepared from mucosal surface scrapings. These studies are thus limited in characterisation of the histological distribution of the IGF 1 receptor because of the difficulty in achieving homogeneity of membrane preparation from heterogeneous tissue sections. This study used biotinylated IGF 1 and anti-IGF 1 receptor antibody to determine the in situ distribution of

\section{Materials and methods}

BIOTINYLATION OF IGF 1

IGF 1 was biotinylated using N-biotinyl- $\omega$ aminocaproic-acid-N-hydroxy succinimide (Enzotin kit; Enzo Biochem, Inc). Biotinylation was assessed by SDS-PAGE $^{8}$ followed by western blotting' and visualisation with streptavidin conjugated horseradish peroxidase using 3-amino-9-ethylcarbazole as substrate.

Receptor binding capacity was assessed by competitive binding assay with radiolabelled IGF 1 to ovine intestinal mucosal membranes. ${ }^{10}$ Briefly, assays were performed in $5 \mathrm{ml}$ polystyrene tubes. Membrane preparations, stored in liquid nitrogen, were allowed to thaw at room temperature and were homogenised with a glass on glass loose fitting homogeniser before use. Into each tube was placed $200 \mu \mathrm{l}$ of $25 \mathrm{mM}$ TRIS, $10 \mathrm{mM} \mathrm{MgCl}_{2}$, containing $0 \cdot 1 \%$ bovine serum albumin followed by $100 \mu \mathrm{l}$ of membrane protein $(1 \mathrm{mg} / \mathrm{ml}) .\left[{ }^{125} \mathrm{I}\right] \mathrm{IGF} 1$, iodinated by the method of Zapf $e t a l,{ }^{11}$ was added to each tube in $100 \mu \mathrm{l}$ aliquots $(30000 \mathrm{cpm} ; 195 \mathrm{pg})$. Competitive ligands were added in $100 \mu \mathrm{l}$ volumes at a final concentrations range of $0.01 \mathrm{nM}$ to $100 \mathrm{nM}$ and the tubes were gently vortexed and left shaking at $4^{\circ} \mathrm{C}$ overnight. The following day $3 \mathrm{ml}$ of ice cold $25 \mathrm{mM}$ TRIS, $10 \mathrm{mM} \mathrm{MgCl}_{2}, \mathrm{pH} 7 \cdot 4$, was added to each tube. Tubes were vortexed before centrifuging at $3000 \times g$ for 30 minutes. The tubes were decanted and the resultant pellet was counted.

Total binding was determined using only $\left[{ }^{125}\right]$ IGF 1 as ligand. Non-specific binding was determined by the addition of excess unlabelled ligand.

\section{TISSUE SECTIONS}

Tissue was obtained from male Sprague-Dawley rats of approximate weight $200-300 \mathrm{~g}$. Animals were killed by cervical dislocation, and the gut and spleen were immediately removed into liquid nitrogen. Tissue was embedded in an ornithine carbamoyltransferase compound (BDH Ltd, Poole, Dorset, England) and serial $5 \mu \mathrm{m}$ sections were taken by cryostat set at $-20^{\circ} \mathrm{C}$.

\section{IMMUNOHISTOCHEMISTRY}

Tissue sections were fixed in acetone (10 minutes, $4^{\circ} \mathrm{C}$ ) and endogenous peroxidase activity was blocked with methanol: $\mathrm{H}_{2} \mathrm{O}_{2}$ (99:1 ratio of a $33 \%$ solution) for 10 minutes at $4^{\circ} \mathrm{C}$ and subsequently with $10 \mathrm{mM}$ sodium azide during 3,3'-diaminobenzidine (DAB; Sigma Chemical Co Ltd, Poole, Dorset, England) substrate development.
DC Costigan Dr J Ryan, The Children's Research Centre, Our Lady's Hospital for Sick Children, Accepted for publication 29 April 1993
Centre, Our Lady's Children, Dublin, Ireland type 1 IGF receptors in the gut.

\footnotetext{
(
}

- 


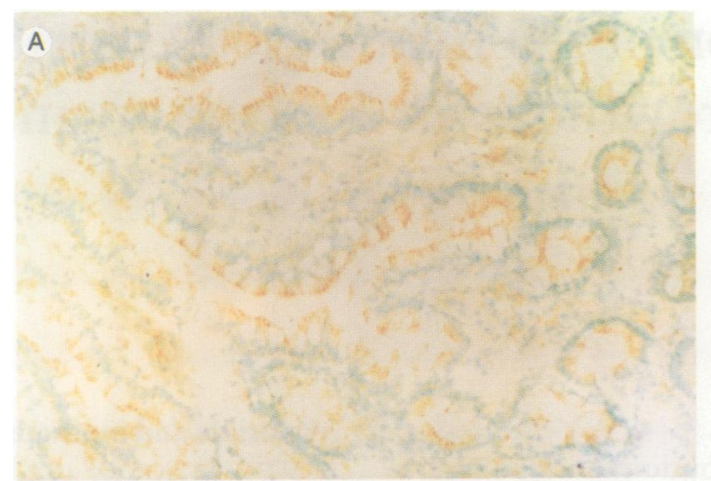

B
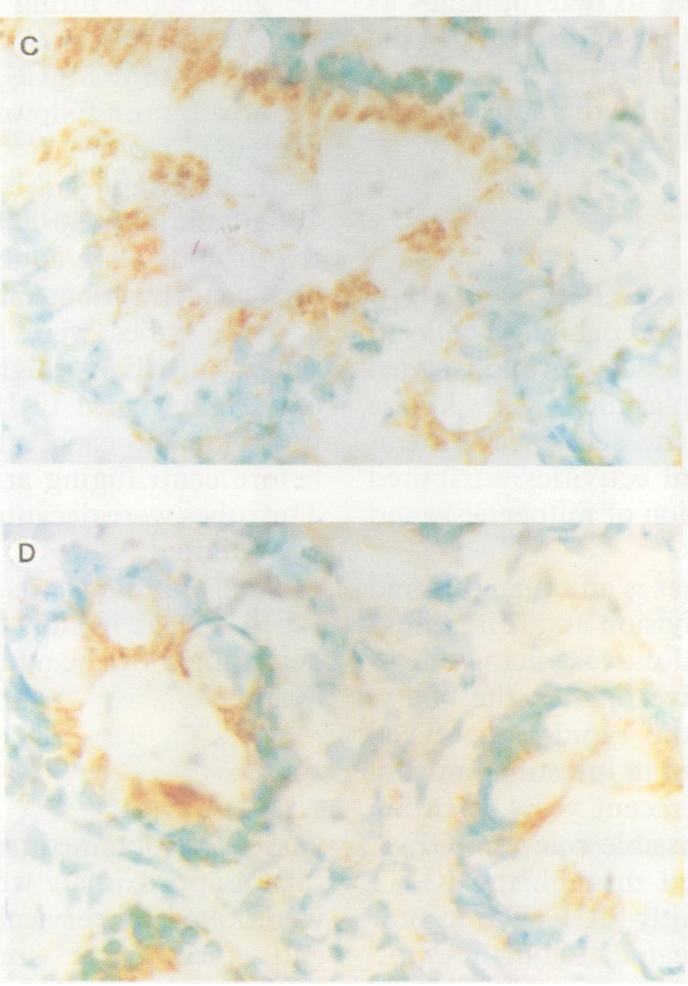

HISTOLOGICAL LOCALISATION OF IGF 1

RECEPTORS

After treatment with $10 \%$ normal human serum for 60 minutes, sections were incubated with either rabbit anti-chromogranin $\mathrm{A}$ antibody at 1/100 dilution (Dako, High Wycombe, Bucks, England) or rabbit anti-IGF 1 receptor antibody $1 / 50$ dilution for 48 hours at $4^{\circ} \mathrm{C}$ (Upstate Biotechnology, Lake Placid, NY). The antiIGF 1 receptor antiserum is specific for the IGF 1 receptor $\alpha$ subunit, and does not cross react with IGF 2 receptor or insulin receptor. The primary antibodies were replaced with normal rabbit
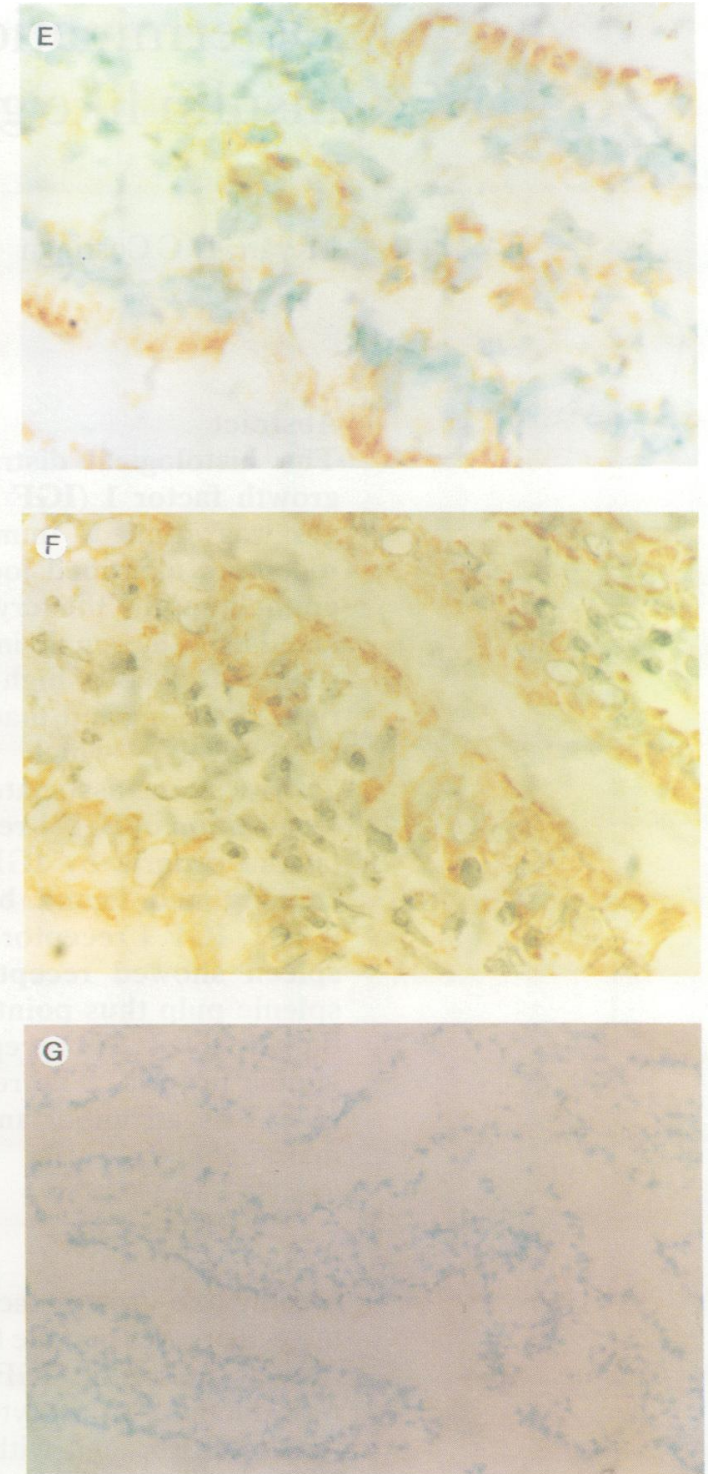

Figure 1: IGF 1 receptor immunostaining in rat intestine with methyl green as counterstain. (A) Magnification $\times 160$ shows the mid gut topology of receptor immunostaining.

Immunostaining at $\times 630$ magnification is shown: $(B)$ on the villi surface epithelium (mid gut); $(C)$ in the crypts (mid gut); $(D)$ in the Brunner's glands (mid gut); and in the lamina propria of $(E)$ distal gut and $(F)$ proximal gut sections. A negative control of villi immunostaining in rat sections $(G)$ at $\times 160$ magnification is shown.

serum for chromogranin A and IGF 1 receptor as negative controls. After incubation, tissue sections were washed three times (15 minutes each) with phosphate buffered saline (PBS), $\mathrm{pH}$ $7 \cdot 4$. Tissue sections were then treated with biotinylated swine anti-rabbit secondary antibody (Dako) at 1/400 dilution for one hour at room temperature. Sections were washed as described previously in PBS before immunostaining. Alternately, tissue sections were incubated with biotinylated IGF $1(0.5 \mathrm{mg} / \mathrm{ml})$ for 24 hours at $4^{\circ} \mathrm{C}$. Sections were washed three times with ice cold PBS (five minutes each). 


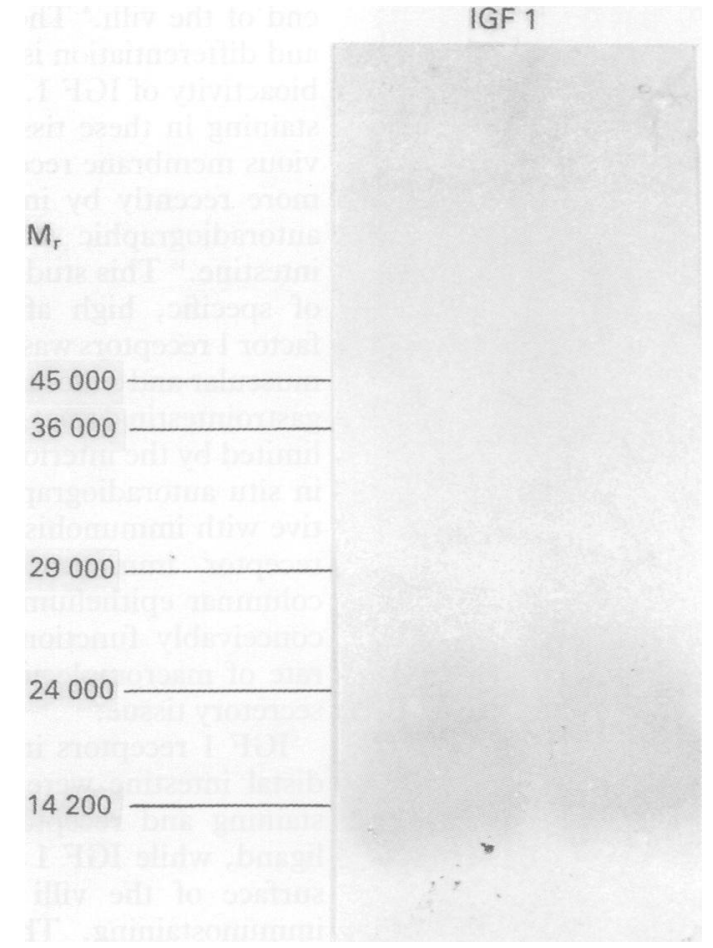

Figure 2: Western blot (12.5\% SDS-PAGE electroblotted onto nitrocellulose) of biotinylated IGF 1 . The blot was developed with streptavidin conjugated horseradish peroxidase with 3-amino-9-ethylcarbozole as substrate.

Localisation of immunostaining was shown by the avidin-biotin peroxidase complex method, using Dako ABC kits.

\section{Results}

IGF 1 immunostaining was seen in rat mid gut (Fig 1A). Immunostaining of IGF 1 receptors was seen on the villi of the small intestine (Fig 1B), the crypts (Fig 1C), and the columnar epithelia of Brunner's glands (Fig 1D). Cellular staining seen in the lamina propria of mid gut (Fig 1B) and distal gut sections (Fig 1E) was diminished in proximal gut (Fig $1 F$ ). A negative control for IGF 1 receptor immunostaining is shown (Fig 1G). The general pattern of immunostaining remained consistent from proximal to distal gut. The intensity of immunostaining on the villi surface epithelium, however, decreased in moving from proximal to distal gut. Conversely, the intensity of cellular straining in the lamina propria increased in moving from proximal to distal gut.

IGF 1 was biotinylated using N-biotinyl- $\omega$ aminocaproic-acid-N-hydroxy succinimide (Fig 2). Biotinylation of IGF 1 resulted in decreased affinity of the ligand for its receptor, as assessed by competitive binding with $\left[{ }^{125}\right.$ I]IGF 1 in membrane receptors prepared from ovine intestinal mucosal scraping ${ }^{10}$ (Fig 3). The comparative potencies of IGF 1 and biotinylated IGF 1 in competitive binding to ovine intestinal mucosal membranes were evaluated by the concentration required to decrease binding of radioligand by $50 \%$. Half maximal inhibition of [125 I]IGF 1 with IGF 1 was seen at $0.1 \mathrm{nM}$ compared with $1.0 \mathrm{nM}$ when in competition with

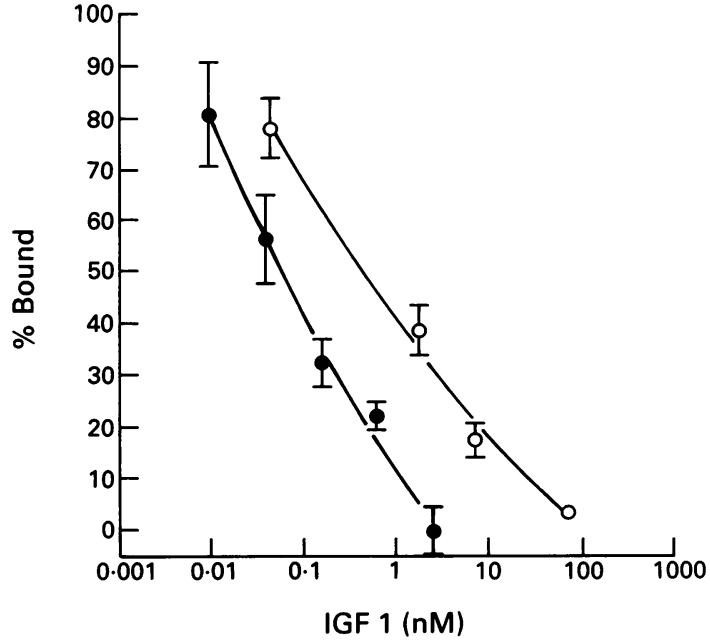

Figure 3: Competitive binding of I $^{125}$ IJIGF 1 with IGF 1 (O) and biotinylated IGF I (O), in ovine intestinal mucosal membranes, is shown.

biotinylated IGF 1 . Biotinylated IGF 1 bound ovine intestinal receptor membrane preparations at roughly 10 -fold lower concentrations than insulin, while [ $\left.{ }^{125} \mathrm{I}\right] \mathrm{IGF} 1$ binding was completely inhibited with $500 \mathrm{nM}$ insulin (data not included). The IGF 2 receptor does not recognise insulin, ${ }^{12}$ thus inferring that biotinylated IGF 1 bound the IGF 1 receptor in ovine intestinal membranes. Biotinylated ligand staining of IGF 1 receptors was not seen in proximal gut sections, while staining in distal gut sections was seen as a cellular pattern limited to the lamina propria (Fig 4).

Chromogranin A immunostaining was used as a positive control for IGF 1 receptor immunostaining in the gut. Staining was restricted to the lamina propria. No immunostaining was seen in the mucosal epithelium (Fig 5). Immunostaining of IGF 1 receptors in spleen was used as a positive control tissue stain for comparison with gut. IGF 1 receptor immunostaining in the spleen was located in the splenic pulp (Fig 6).

\section{Discussion}

Insulin like growth factor 1 is a polypeptide, which has been shown to stimulate macromolecular synthesis, cell division, and differentiation. The biological activity of IGF 1, when acting independently, additionally or synergistically with other growth factors, such as platelet derived growth factor, is in raising the cell growth rate. ${ }^{1314}$ The gastrointestinal tract constitutes an organ in a constant high state of tissue repair and renewal. ${ }^{4}$ This study identifies the histological distribution of IGF 1 receptor densities in the gut. It also discusses the potential role of IGF 1 comparative with the known functions of particular tissue types, which show positive IGF 1 receptor immunostaining.

IGF 1 receptor immunostaining was seen in the stem cells of the crypts of Lieberkühn and the epithelial layer of the villi. Crypts represent regions of rapid mitosis and differentiation, providing for a continual turnover of cells that differentiate into columnar and goblet cells as they migrate from the crypts towards the luminal 
Figure 4: IGF 1 receptor staining in rat distal gut with biotinylated IGF 1 and methyl green as counterstain. Magnification $\times 160$.

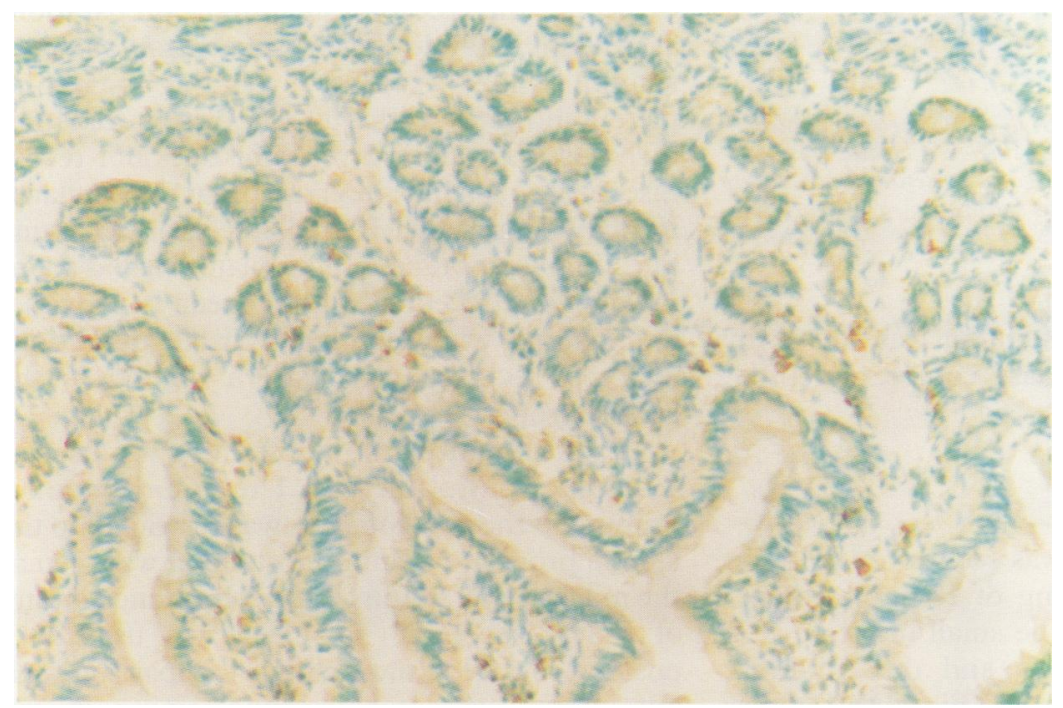

Figure 5: Chromogranin A immunostaining in rat mid gut with methyl green as counterstain. Magnification $\times 160$. end of the villi. ${ }^{+}$The rapid rate of cell division and differentiation is consistent with the known bioactivity of IGF $1 .^{23}$ IGF 1 receptor immunostaining in these tissues is corrobrated by previous membrane receptor binding studies ${ }^{5-7}$ and more recently by insulin like growth factor 1 autoradiographic characterisation in rabbit intestine. ${ }^{15}$ This study showed that a single class of specific, high affinity insulin like growth factor 1 receptors was distributed throughout the muscular and mucosal layers of the entire rabbit gastrointestinal tract. These data, however, were limited by the interior cellular detail afforded by in situ autoradiographic visualisation comparative with immunohistochemical staining. IGF 1 receptor immunostaining was seen in the columnar epithelium of Brunner's glands, and conceivably functions in stimulating the high rate of macromolecular synthesis in this active secretory tissue.

IGF 1 receptors in the lamina propria of rat distal intestine were shown both by immunostaining and receptor binding of biotinylated ligand, while IGF 1 receptors on the epithelial surface of the villi were only detectable by immunostaining. The diminished binding of biotinylated IGF 1 to membrane receptors, comparative with the native peptide (Fig 3), is possibly a result of steric hindrance caused by the addition of biotin molecules close to the receptor binding site. The discrepancy in measurement sensitivity between anti-IGF 1 antibody and biotinylated IGF 1 allows for comparison of the cellular staining in the lamina propria and epithelial staining on the villi. An absence of staining in the epithelial layer with biotinylated IGF 1, when staining within the lamina propria shows definite cellular positivity, points to increased receptor densities, or increased receptor affinity in these cells comparative with the villus epithelium and the crypts.

The level of cellular staining of IGF 1 receptors in the lamina propria would represent particularly active macromolecular synthesis. ${ }^{3}$ The cell populations in the lamina propria include fibroblasts, connective tissue fibres, lymphocytes, eosinophilic leucocytes, mast cells, and macrophages. ${ }^{16}$ Only mast cells and macrophages, however, fit the criteria of a compatible histological distribution comparative with the immunostained/biotinylated ligand bound cells, and retain a biological activity, which might require high level IGF 1 receptor expression; that is, mast cells and macrophages actively produce cell mediators such as leukotrienes ${ }^{17}$ and cytokines ${ }^{18}$ as well as other peptides. IGF 1 immunostaining on the recticuloendothelium of the spleen would support macrophage staining in the lamina propria.

The localisation of IGF 1 receptors on different tissues within the gastrointestinal tract suggests varied functions for IGF 1 within this organ. Receptor localisation within Brunner's glands, and possibly on macrophages in the lamina propria, implies a function for IGF 1 in regulating macromolecular synthesis of enzymes or cell mediators, or both. Certainly, the regulatory role of IGF 1 on RNA, DNA, and protein synthesis is well reported. ${ }^{19} 20$ Localisation of IGF 1 receptors on crypts and villi 
epithelium suggests a functional role for IGF 1 in cell growth and differentiation, thus suggesting a possible role for IGF 1 in gut maintenance and repair. To date, there have been few investigations of the role of IGF 1 in the gut. Available data, however, implicate IGFs as having a possible pivotal role in gastrointestinal maintenance, repair, and possibly development. ${ }^{-72122}$ The histological distribution of IGF 1 receptors in the gut would support such a role for IGF 1 .

The authors wish to thank Barry Kierce for his helpful advice and comments, Pauline Johnson for her technical input, and Olive Reddy for typing this manuscript. We also wish to thank Kabi Reddy for typing this manuscript. We also
Vitrum Sweden for kindly supplying IGF 1 .

1 Czech M. Signal transmission by the insulin-like growth factors. Cell 1989; 59: 235-8.

2 McCarthy TL, Centrella M, Canalis E. Insulin-like growth factor (IGF) and bone. Connect Tissue Res 1989; 20: 277-82.

3 Johnson SE, Allen RE. The effect of bFGF, IGF-1 and TGFbeta on RMo skeletal muscle cell proliferation and differentiation. Exp Cell Res 1990; 187: 250-4.

4 MacDonald WC, Trier JS, Everett NB. Cell proliferation and migration in the stomach, duodenum and rectum of man: radioautographic studies. Gastroenterology 1964; 46: 40517.

5 Laburthe M, Rouyer-Fessard C, Gammeltoft S. Receptors for insulin-like growth factors I and II in rat gastrointestinal insulin-like growth factors I and II in rat gastr
epithelium. Am $\mathcal{F}$ Physiol 1988; 254: G457-62.

6 Pillon DJ, Haskell JF, Atchison JA, Ganapathy V, Liebach FH. Receptors for IGF-1, but not IGF-II, on proximal colon epithelial cell apical membranes. Am $\mathcal{F}$ Physiol 1989; 257: E27-34.

7 Schober DA, Simmen FA, Hadsell DL, Baumrucker CR. Perinatal expression of type 1 IGF receptors in porcine small intestine. Endocrinology 1990; 126: 1125-32.

8 Laemmli UK. Cleavage of structural proteins during the assembly of the head of bacteriophage T4. Nature 1970;227: 280-5.

9 Towbin H, Staehelin T, Gordon J. Electrophoretic transfer of proteins from polyacrylamide gels to nitrocellulose sheets: procedure and some applications. Proc Natl Acad Sci USA 1979; 76: 4350-4.
10 Kessler M, Acuto O, Storelli C, Murer H, Muller M, Semenza $G$. A modified procedure for the rapid preparation of efficiently transporting vesicles from small intestinal brush border membranes. Their use in investigating some properties of D-glucose and choline transport systems. Biochim Biophys Acta 1978; 506: 136-54.

11 Zapf J, Walter H, Froesch ER. Radioimmunological determination of insulin-like growth factors I and II in normal subjects and in patients with growth disorders and extrapancreatic tumor hypoglycemia. F Clin Invest 1981; 68: pancreatic

12 Rechler MM, Nissley SP. The nature and regulation of the receptors for insulin-like growth factors. Annu Rev Physiol 1985; 47: 425-42.

13 Spencer EM, Skover G, Hunt TK. Somatomedins: Do they play a pivotal role in wound healing? Prog Clin Biol Res 1988; 266: 103-16.

14 Lynch SE, Colvin RB, Antoniades HN. Growth factors in wound healing: single and synergistic effects on partial thickness procine skin wounds. $\mathcal{F}$ Clin Invest 1989; 84: 640-6.

15 Termanini B, Nardi RV, Finan TM, Parikh I, Korman LY. Insulin-like growth factor 1 receptors in rabbit gastroinsulin-like growth factor 1 receptors in rabbit gastrointestinal tract. Characterisation and au

16 Williams PL, Warwick R, Dyson M, Bannister LH. Splanchnology. In: Grays Anatomy. 37th ed. Edinburgh: Churchill Livingstone, 1989: 1246-8.

17 Walsh CE, Waite BM, Thomas MJ, DeChatelet LR. Release and metabolism of arachidonic acid in human neutrophils. f Biol Chem 1981; 256: 7228-34.

18 Johnston RB. Monocytes and macrophages. $N$ Engl f Med 1988; 318: 747-52.

19 Salmon WD, DuVall MR. In vitro stimulation of leucine incorporation into muscle and cartilage protein by a serum fraction with sulphation factor activity: differentiation of effects from those of growth hormone and insulin. of effects from those of grow

20 Rechler MM, Fryklund L, Nissley S, Hall K, Podskalny JM, Skottner A, et al. Purified human somatomedin A and rat multiplication stimulating activity. Mitogens for cultured fibroblasts that cross-react with the same growth peptide receptors. Eur F Biochem 1978; 82: 5-12.

21 Lund PK, Ulshen MH, Rountree DB, Selub SE, Buchan AM. Molecular biology of gastrointestinal peptides and growth factors: relevance to intestinal adaptation. Digestion 1990; 46 (suppl 2): 66-73.

22 Young GP, Taranto TM, Jonas HA, Cox AJ, Hogg A, Werther GA. Insulin-like growth factors and the developing and natural rat small intestine: receptors and biological actions. Digestion 1990; 46 (suppl 2): 240-52. 